\title{
Occupational respiratory disease in the United Kingdom 1989: a report to the British Thoracic Society and the Society of Occupational Medicine by the SWORD project group
}

\author{
Prepared by S K Meredith, V M Taylor, J C McDonald
}

\begin{abstract}
A voluntary scheme for the surveillance of work related and occupational respiratory disease (SWORD) was established in January 1989 with help from the British Thoracic Society and the Society of Occupational Medicine and support from the Health and Safety Executive. Three hundred and fifty four chest physicians representing $90 \%$ of the chest clinics in the United Kingdom and 361 occupational physicians submit reports regularly of newly diagnosed cases of work related respiratory illness with information on age, sex, residence, occupation, and suspected causal agent. In 1989 2101 cases were notified, of which frequent diagnoses were asthma (26\%), mesothelioma $(16 \%)$, pneumoconiosis $(15 \%)$, benign pleural disease $(11 \%)$, and allergic alveolitis (6\%). Incidence rates calculated against denominators from the Labour Force Survey showed very large differences between occupational groups, especially for asthma and asbestos related diseases. Substantial regional variation in the incidence of asthma was not explained by the geographical distribution of high risk industries and was probably due to differing levels of ascertainment. The results imply that the true frequency of acute occupational respiratory disease in the United Kingdom may have been three times greater than that reported.
\end{abstract}

Few countries have satisfactory means of monitoring the occurrence of work related diseases, without which control measures and related research are difficult to direct. Acute, chronic, and malignant

Epidemiological Research Unit, National Heart and Lung Institute, London Chest Hospital, Bonner Road, London E2

S K Meredith, V M Taylor, J C McDonald diseases of the respiratory tract caused by a wide and changing variety of dusts, gases, and fumes have a major impact on health. An increasing proportion of the work of chest physicians is concerned with the recognition and management of these diseases. The task calls for up to date knowledge on the types of illness being seen by colleagues and the range of agents that might be responsible. For many years weekly analyses by the Public Health Laboratory Service of informal reports submitted by public health and hospital laboratories have been of great value in the control of communicable disease. It was thought that a similar approach might be of equal use in the field of occupational health. ${ }^{1}$

In 1987, during discussions with representatives of the British Thoracic Society (BTS) and the Society of Occupational Medicine (SOM), a plan was agreed for the voluntary reporting by members of the two societies of new cases of occupational respiratory illness. A detailed proposal was submitted to the Health and Safety Executive (HSE) and approved for funding for an initial three year period 1989-91. The objectives of the scheme were (1) to monitor the frequency of work related respiratory disease; (2) to promote the early recognition, investigation, and control of new problems; (3) to provide rapid feedback and information to participants; and (4) to undertake collaborative investigations where indicated.

In 1989, the first full year of operation, the scheme was established and, after minor modification for 1990 , is now running smoothly. The methods and procedures used and the results obtained are the subject of this report. This programme for surveillance of work related and occupational respiratory disease is known by the acronym SWORD.

\section{Methods}

RECRUITMENT

During the last quarter of 1988 , letters were sent by the presidents of the SOM and BTS to all members in the United Kingdom inviting their participation. 
It was explained that monthly reports were required, including nil returns, of all newly diagnosed cases of respiratory disease thought to be due to work related factors. By the end of 1988, when reporting was to begin, 211 chest physicians had joined the scheme and during the next few months this figure increased to 348. Fewer occupational physicians responded, principally because of concern over aspects of confidentiality, and the fact that they were less likely to be the first to see new cases. These points were specifically addressed in letters sent out to SOM members in the second half of 1989 , as a result of which the number of occupational physicians participating rose to 350 by the end of the year.

In the later stages of recruitment it became clear that some doctors see very few suitable cases and were therefore reluctant to submit monthly reports. To maximise the national coverage the protocol was extended to include those who would report every three months, every six months, and even annually. Table 1 shows the resulting totals. The chest physicians represent $83 \%$ of consultants listed in the 1988 handbook, Thoracic Medical Services in the United Kingdom, ${ }^{2}$ and include at least one physician in $90 \%$ of the country's chest clinics. The number of members of SOM in clinical practice is being sought by survey but is not yet available.

\section{PROCEDURE}

Report cards are sent to each participating doctor before the start of the period to be covered with a request that the card be returned immediately after the end of that period. A monthly digest of reported cases by diagnostic category with a brief commentary is distributed to all participants by the middle of the next month and a detailed analysis is sent every quarter.

The report card is $8^{\prime \prime} \times 4^{\prime \prime}$ in size, with boxes on the front to record the number of new cases seen under 10 diagnostic headings; on the back is space for entering the age, sex, place of residence, type of work, and suspected agent for each case. Physicians are asked to report any newly diagnosed respiratory illness that they believe is due to occupational or work related exposure. In 1989 the diagnostic categories were acute pulmonary oedema, allergic alveolitis, asthma, building-related illness, byssinosis, infectious disease, lung cancer (in the presence of pulmonary fibrosis), malignant mesothelioma, pneumoconiosis, and any other diagnoses. Minor changes were made to the card at the beginning of 1990: acute pulmonary oedema was replaced by inhalation accidents, pulmonary fibrosis was no longer a requirement for lung cancer, and two new categories-bronchitis and benign pleural diseasewere added. On the back of the card the initials of patients were requested to aid detection of duplicate
Table 1 Participation in the SWORD project

\begin{tabular}{lcc}
\hline $\begin{array}{l}\text { Reporting } \\
\text { frequency }\end{array}$ & $\begin{array}{l}\text { No of chest } \\
\text { physicians }\end{array}$ & $\begin{array}{l}\text { No of occupational } \\
\text { physicians }\end{array}$ \\
\hline Monthly & $277^{\star}$ & $57^{\star}$ \\
Quarterly & 66 & 68 \\
Bi-annually & 3 & 83 \\
Annually & 8 & 153 \\
Total & 354 & 361 \\
\hline
\end{tabular}

*Including 34 physicians (16 chest and 18 occupational) who report monthly through colleagues.

reporting. We also made it clear in 1990 that only cases due to occupational or work related factors should be reported to avoid the inclusion of the few cases due to recreational or other exposures.

The information from each card is entered on a microcomputer database (dBase IV). Place of residence is coded according to standard administrative region, and occupation is coded to the 1980 Classification of Occupations. $^{3}$

\section{RATES}

Data from the 1988 Labour Force Survey were obtained from the Office of Population Censuses and Surveys and were used to estimate incidence rates in the working population by age, sex, occupation, and region of residence in each diagnostic group. Confidence intervals were calculated based on the Poisson distribution. ${ }^{4}$

\section{Results}

REPORTED CASES

There were 2101 cases reported of work related respiratory disease diagnosed in 1989. Table 2 gives

Table 2 Cases and crude annual rates by diagnostic category

\begin{tabular}{lcc}
\hline Diagnostic category & No (\%) & $\begin{array}{l}\text { Ratel } \\
\text { million } / y^{\star}\end{array}$ \\
\hline Inhalation accidents & $72(3 \cdot 4)$ & 3 \\
$\quad$ Acute pulmonary oedema & 15 & \\
Other & 57 & \\
Allergic alveolitis & $133(6 \cdot 3)$ & 5 \\
Asthma & $554(26 \cdot 4)$ & 22 \\
Building related illness & $217(10 \cdot 3)$ & 9 \\
Byssinosis & $23(1 \cdot 1)$ & 1 \\
Infectious diseases & $100(4 \cdot 8)$ & 4 \\
Lung cancer (with pulmonary fibrosis) & $51(2 \cdot 4)$ & 2 \\
Malignant mesothelioma & $340(16 \cdot 2)$ & 13 \\
Pneumoconiosis & $322(15 \cdot 3)$ & 13 \\
Benign pleural disease & $221(10 \cdot 5)$ & 9 \\
Other diagnoses & $68(3 \cdot 2)$ & 3 \\
Bronchitis/emphysema & 25 & \\
Lung cancer & 12 & \\
Other & 26 & \\
Unspecified & 5 & \\
Total & $2101(100 \%)$ & 84 \\
\hline
\end{tabular}

* Based on the 1988 Labour Force Survey estimate of the United Kingdom working population. 
the distribution by diagnostic category. The largest single group was asthma, which accounted for $26 \%$ of reported cases. The mineral dust diseases-lung cancer in the presence of pulmonary fibrosis, malignant mesothelioma, and pneumoconiosis-together made up $34 \%$ of the cases. A variety of conditions were reported under other diagnoses, the most common of which was benign pleural disease (221 cases); this has been listed in table 2 as a separate category. Fifty seven inhalation accidents were reported, presumably insufficiently severe to be included under acute pulmonary oedema.

Tables 3, 4, and 5 set out the principal agents suspected within each diagnostic category. Of the 554 cases of occupational asthma (see table 3), 282 $(51 \%)$ were attributed to agents on the prescribed list, ${ }^{5}$ compared with 222 patients who qualified for disablement benefit for asthma in Great Britain in
$1988{ }^{6}$ With the exception of cases thought to be due to isocyanates, the Department of Social Security (DSS) and SWORD data were similar, although the SWORD figures included 10 cases resident in Northern Ireland who would be excluded from the DSS statistics. A further 214 cases (39\%) reported to the SWORD project were attributed to agents that are not recognised for disablement benefit, and another $10 \%$ for which the suspected agent was either unknown or not specified. Isocyanates were the agents most commonly suspected overall, accounting for $120(22 \%)$ asthma cases, nearly twice as many as the number awarded compensation in 1988.

Malignant mesotheliomas and lung cancers in the presence of pulmonary fibrosis were virtually all attributed to asbestos, as were most of the pneumoconioses (see table 4). Nevertheless, nine cases of mesothelioma were reported without known

Table 3 Suspected agents in occupational asthma

\begin{tabular}{|c|c|c|c|c|}
\hline $\begin{array}{l}\text { Prescribed } \\
\text { causes }\end{array}$ & $\begin{array}{l}\text { Compensated } \\
\text { cases }^{\star} \text { (no) }\end{array}$ & $\begin{array}{l}\text { SWORD cases } \\
(\text { no }(\%))\end{array}$ & Non-prescribed causes & $\begin{array}{l}\text { SWORD cases } \\
(\text { no }(\%))\end{array}$ \\
\hline $\begin{array}{l}\text { Flour/grain dusts } \\
\text { Wood dusts } \\
\text { Other prescribed plant dusts } \\
\text { Laboratory animals/insects }\end{array}$ & $\begin{array}{r}40 \\
28 \\
1 \\
9\end{array}$ & $\begin{array}{rr}42 & (8) \\
31 & (6) \\
0 & (0) \\
21 & (4)\end{array}$ & Other plant dusts, fungi and animal antigens & $38 \quad(7)$ \\
\hline $\begin{array}{l}\text { Isocyanates } \\
\text { Azodicarbonamide } \\
\text { Antibiotics } \\
\text { Proteolytic enzymes }\end{array}$ & $\begin{array}{r}64 \\
5 \\
6 \\
2\end{array}$ & $\begin{array}{r}120(22) \\
6(1) \\
5(1) \\
5(1)\end{array}$ & $\begin{array}{l}\text { Formaldehyde } \\
\text { Ethylene diamine } \\
\text { Chlorine } \\
\text { Ammonia } \\
\text { Methylene chloride } \\
\text { Glutaraldehyde } \\
\text { Other pharmaceuticals } \\
\text { Other chemicals }\end{array}$ & $\begin{aligned} & 7(1) \\
& 5(1) \\
& 5(1) \\
& 3(<1) \\
& 2(<1) \\
& 2(<1) \\
& 3(<1) \\
& 36 \quad(7)\end{aligned}$ \\
\hline Platinum salts & 12 & $5(1)$ & $\begin{array}{l}\text { Aluminium potroom emissions } \\
\text { Cobalt } \\
\text { Welding fume } \\
\text { Chrome }\end{array}$ & $\begin{array}{r}11 \quad(2) \\
8 \quad(1) \\
4(<1) \\
3(<1)\end{array}$ \\
\hline \multirow[t]{2}{*}{$\begin{array}{l}\text { Solder flux } \\
\text { Hardening agents }\end{array}$} & $\begin{array}{l}24 \\
31\end{array}$ & $\begin{array}{l}32(6) \\
15(3)\end{array}$ & $\begin{array}{l}\text { Paints } \\
\text { Glues } \\
\text { Hair/cleaning products and disinfectants } \\
\text { Inks and dyes } \\
\text { Cutting oil } \\
\text { Insecticides/fungicides } \\
\text { Fibreglass }\end{array}$ & $\begin{array}{r}15 \quad(3) \\
12 \quad(2) \\
11 \quad(2) \\
7 \quad(1) \\
7 \quad(1) \\
3(<1) \\
3(<1)\end{array}$ \\
\hline & & & Other specified agents & $29 \quad(5)$ \\
\hline Total & 222 & $282(51) \dagger$ & Total & $214(39) \dagger$ \\
\hline
\end{tabular}

*New cases qualifying for disablement benefit in Great Britain in 1988 by causative agent (Department of Social Security).

†In a further 58 cases $(10 \%)$ the suspected agent was unknown or not specified.

Table 4 Suspected agents for the mineral dust diseases

\begin{tabular}{|c|c|c|c|c|}
\hline \multirow[b]{2}{*}{ Agent } & \multicolumn{4}{|c|}{ Disease (No (\%)) } \\
\hline & Lung cancer & Mesothelioma & Pneumoconiosis & Benign pleural disease \\
\hline Total & $51(100)$ & $340(100)$ & $322(100)$ & $221(100)$ \\
\hline
\end{tabular}

«No known exposure to asbestos. 
Table 5 Suspected agents for other diseases

\begin{tabular}{|c|c|c|c|}
\hline Diagnostic category & Total & Suspected agents & No of cases (\%) \\
\hline Acute pulmonary oedema and other inhalation accidents & 72 & $\begin{array}{l}\text { Chlorine } \\
\text { Tellurium } \\
\text { Hydrochloric acid } \\
\text { Ammonia } \\
\text { Carbon monoxide } \\
\text { Sulphur dioxide } \\
\text { Ethyl acetate } \\
\text { Other chemicals } \\
\text { Paint fume } \\
\text { Metal fume } \\
\text { Smoke/fume from burning } \\
\text { Not stated }\end{array}$ & $\begin{array}{l}16(22) \\
5(7) \\
4(6) \\
2(3) \\
2(3) \\
2(3) \\
2(3) \\
15(21) \\
6(8) \\
5(7) \\
12(17) \\
1(1)\end{array}$ \\
\hline Allergic alveolitis & 133 & $\begin{array}{l}\text { Birds } \\
\text { Other animal antigens } \\
\text { Moulds/fungi } \\
\text { Flour/grain/hay } \\
\text { Other } \\
\text { Not stated }\end{array}$ & $\begin{aligned} & 77(58) \\
& 2(2) \\
& 22(17) \\
& 7(5) \\
& 11(8) \\
& 14(11)\end{aligned}$ \\
\hline Byssinosis & 23 & $\begin{array}{l}\text { Cotton } \\
\text { Flax } \\
\text { Not stated }\end{array}$ & $\begin{array}{c}20(87) \\
1(4) \\
2(9)\end{array}$ \\
\hline Infectious diseases & 100 & $\begin{array}{l}\text { Influenza-like illness } \\
R \text { burnetti } \\
\text { Legionella } \\
C \text { psittaci } \\
M \text { tuberculosis } \\
\text { Other } \\
\text { Not stated }\end{array}$ & $\begin{array}{l}35(35) \\
23(23) \\
12(12) \\
9(9) \\
8(8) \\
6(6) \\
7(7)\end{array}$ \\
\hline
\end{tabular}

exposure to asbestos. Few cases of pneumoconiosis in coal workers were reported, perhaps because those new cases that now occur are detected mainly by periodic surveillance within the mining industry. We hope to obtain more information on these cases during the course of the project.

The combined total of inhalation accidents and pulmonary oedema amounted to 72 cases (see table $5)$; of these $16(22 \%)$ were in men with respiratory symptoms resulting from inhalation of chlorine; the others were due to a variety of chemicals and fume.

Over half of the cases of allergic alveolitis were attributed to birds, mainly in the context of recreational bird keeping. Only 39 cases of allergic alveolitis had a clear occupational cause, usually associated with farming ( 26 cases).

The building related disorders and the infectious disease categories contain cases reported by participants after outbreak investigations. The outbreaks included an influenza-like illness affecting 35 employees in an isolated workplace, and cases from a large outbreak of $Q$ fever in the West Midlands. Of 218 cases of building-related disease, 190 were found in an investigation of three office buildings in the midlands.

\section{SEX AND AGE DISTRIBUTION}

The sex of the patient was stated in $85 \%$ of reported cases; of those $84 \%$ were men, but the proportion varied with the diagnosis. Although $29 \%$ of the patients with allergic alveolitis and asthma were female, only $8 \%$ of cases in the remaining diagnostic categories were women. The age distribution also varied with diagnosis: $52 \%$ of cases of allergic alveolitis and asthma were aged less than 45 years, compared with only $12 \%$ in the other diagnostic groups combined.

\section{INCIDENCE RATES}

Annual incidence rates were calculated per million working population in the United Kingdom (1988 Labour Force Survey) for each diagnostic category (see table 2). The categories with very small numbers-inhalation accidents, byssinosis, infectious diseases, and other diagnoses-were not analysed further. Because some diseases such as those due to mineral dusts typically develop some 20 or 30 years after first exposure the denominators were not ideal for these diagnostic groups, but more appropriate figures are not available.

For both asthma and allergic alveolitis the annual incidence in working men was roughly twice that found in women and rose with age in both sexes. The figures for asthma were 9 per million working women and 17 per million working men aged $16-29$ years; 13 per million and 22 per million respectively for those aged 30-44 years; and 16 per million and 36 per million respectively for those older than 45 years. In the mineral dust diseases, the age specific rates were low in the young and very high in the older age groups, reflecting the long latency of these conditions. 


\section{OCCUPATIONAL RATES}

Considerable variation occurred in the annual incidence of reported cases by occupation. The overall rate of asthma was 22 per million, but it ranged from less than 10 per million in professional, managerial, clerical, and selling occupational groups to 114 per million in industries processing non-metal and electrical materials and those engaged in painting, assembly, and packing. Table 6 gives the rates in selected occupational sub-groups that experienced 5-30 times the risk of occupational asthma of the general population.

Differences of a similar magnitude were seen in the mineral dust diseases. For simplicity, the asbestos related diseases-asbestosis, malignant meso- thelioma, and lung cancer with pulmonary fibrosishave been combined ( 557 cases). The rate of asbestos related disease in the whole working population was 22 per million, ranging from less than 3 per million in professional, managerial, clerical, and agricultural occupations to over 100 per million in metal and electrical processing and making, and construction industries. Table 7 gives the rates for men in selected high risk occupations.

\section{REGIONAL RATES}

Considerable differences were found in the regional rates for asbestos related diseases and occupational asthma. The range for asthma (see table 8), was from

Table 6 Incidence of occupational asthma in high risk occupations

\begin{tabular}{|c|c|c|c|c|}
\hline Occupational group & Cases & Population & Rate/million/y & $(95 \% C I)$ \\
\hline $\begin{array}{l}\text { Welders/solderers/electronic assemblers } \\
\text { Laboratory technicians and assistants } \\
\text { Metal making and treating } \\
\text { Plastics making and processing } \\
\text { Bakers } \\
\text { Chemical processors } \\
\text { Coach and spray painters } \\
\text { Other painters }\end{array}$ & $\begin{array}{l}35 \\
26 \\
14 \\
27 \\
29 \\
31 \\
35 \\
21\end{array}$ & $\begin{array}{r}220068 \\
127478 \\
56270 \\
66005 \\
70839 \\
73189 \\
54737 \\
201225\end{array}$ & $\begin{array}{l}159 \\
204 \\
249 \\
409 \\
409 \\
424 \\
639 \\
104\end{array}$ & $\begin{array}{l}(111-221) \\
(133-299) \\
(136-417) \\
(270-595) \\
(274-588) \\
(288-601) \\
(445-889) \\
(65-160)\end{array}$ \\
\hline
\end{tabular}

Table 7 Asbestos related disease ${ }^{\star}$ in men in high risk occupations

\begin{tabular}{|c|c|c|c|c|}
\hline Occupational group & No of cases & Population & Rate/million/y & $(95 \% C I)$ \\
\hline $\begin{array}{l}\text { Electricians and power plant operators } \\
\text { Building and construction workers (including laggers) } \\
\text { Plumbers and heating engineers } \\
\text { Boiler operators } \\
\text { Shipyard and dock workers }\end{array}$ & $\begin{array}{r}40 \\
100 \\
33 \\
14 \\
77\end{array}$ & $\begin{array}{r}354579 \\
728202 \\
184872 \\
9862 \\
47792\end{array}$ & $\begin{array}{r}113 \\
137 \\
179 \\
1420 \\
1611\end{array}$ & $\begin{array}{c}(81-154) \\
(112-167) \\
(123-251) \\
(776-2412) \\
(1271-2014)\end{array}$ \\
\hline
\end{tabular}

^Includes cases of asbestosis, lung cancer with pulmonary fibrosis and malignant mesothelioma.

Table 8 Regional rates of occupational asthma

\begin{tabular}{|c|c|c|c|c|}
\hline Region & $\begin{array}{l}\text { Observed } \\
\text { (Rate/million/y) }\end{array}$ & $\begin{array}{l}\text { Expected }{ }^{\star} \\
(\text { Rate/million } / y)\end{array}$ & Observed/expected & $(95 \% C I)$ \\
\hline $\begin{array}{l}\text { Tyne and Wear } \\
\text { Rest of North } \\
\text { South Yorkshire } \\
\text { West Yorkshire } \\
\text { Rest of Yorkshire and Humberside } \\
\text { East Midlands } \\
\text { East Anglia } \\
\text { London } \\
\text { Rest of South East } \\
\text { South West } \\
\text { West Midlands Metropolitan County } \\
\text { Rest of West Midlands } \\
\text { Greater Manchester } \\
\text { Merseyside } \\
\text { Rest of North West } \\
\text { Wales } \\
\text { Central Clydeside } \\
\text { Rest of Scotland } \\
\text { Northern Ireland }\end{array}$ & $\begin{array}{r}39 \\
46 \\
23 \\
8 \\
23 \\
15 \\
19 \\
12 \\
13 \\
12 \\
63 \\
21 \\
13 \\
35 \\
30 \\
24 \\
11 \\
28 \\
18\end{array}$ & $\begin{array}{l}20 \\
24 \\
21 \\
24 \\
22 \\
24 \\
21 \\
15 \\
18 \\
19 \\
23 \\
22 \\
23 \\
19 \\
22 \\
21 \\
20 \\
21 \\
21\end{array}$ & $\begin{array}{l}1.95 \\
1.92 \\
1.10 \\
0.33 \\
1.05 \\
0.63 \\
0.91 \\
0.80 \\
0.72 \\
0.63 \\
2.74 \\
0.96 \\
0.57 \\
1.84 \\
1.36 \\
1.14 \\
0.55 \\
1.33 \\
0.86\end{array}$ & $\begin{array}{l}(1.15-3.10) \\
(1.33-2.63) \\
(0.57-1.91) \\
(0.13-0.67) \\
(0.59-1.68) \\
(0.38-0.88) \\
(0.52-1.38) \\
(0.53-1.07) \\
(0.56-0.89) \\
(0.42-0.95) \\
(2.13-3.44) \\
(0.64-1.41) \\
(0.30-0.91) \\
(1.11-2.84) \\
(0.91-1.91) \\
(0.76-1.67) \\
(0.20-1.10) \\
(0.95-1.81) \\
(0.43-1.57)\end{array}$ \\
\hline
\end{tabular}

*The expected rate for a region was calculated by applying the occupational group specific rate to the population employed in each occupational group in the region and then dividing the sum of those expected numbers by the total working population in the region. 
8 per million in West Yorkshire to 63 per million in the West Midlands Metropolitan County. The regional rates of asbestos related disease showed an even wider range: very low rates were seen in East Anglia (10 per million), Greater Manchester (11 per million), the West Midlands excluding the Metropolitan County (11 per million), and the South East (14 per million); high rates were reported in West Yorkshire (31 per million), Central Clydeside (33 per million), the North (41 per million), Merseyside (51 per million), and Tyne and Wear 130 per million.

Possible explanations for the variation in regional rates could lie in the geographical distribution of high risk industries or simply in different levels of ascertainment and reporting. This question was considered by estimating expected regional incidence rates for asthma based on the distribution of occupations within each region. Expected numbers of cases were calculated by applying the occupation specific rates to the working population in each occupational group in each region. Table 8 shows the results. Although some differences between regions were to be expected, the magnitude of those seen was much greater than could be explained by the distribution of occupations. Much of the variation is therefore likely to have been due to differences in ascertainment and reporting.

Similar calculations could not be made for asbestos related diseases based on contemporary working population data because of the changes in the numbers employed in certain industries during the past 30 years; the closure of docks and shipyards in particular will have had a substantial impact on both regional and occupation specific rates.

\section{Comment}

In this first year of a new venture the successful way in which the scheme has operated is as important as the results. The response from chest physicians has been excellent and close to complete national coverage has been achieved. It is unreasonable to expect, however, that busy consultants will be able to give top priority to the recognition and reporting of occupational lung disease. We have received periodic returns from nearly all participants, but not always every month and the importance of nil returns may be forgotten. The analyses of regional differences give some indication of the extent of underreporting. Several factors may contribute to this. Not every person with work related respiratory symptoms sees a doctor; not all are referred to a chest physician; an occupational aetiology may not be considered in all cases; and even if correctly diagnosed may not be reported. As overreporting is most unlikely, the true incidence of acute occupational respiratory disease may have been as high as that seen in regions with the highest rates. This suggests an incidence of occupational asthma of about 60 per million, three times the national rate. An accurate estimate of the incidence of mineral dust diseases is more difficult to make because of the changes in industry mentioned above.

The data for 1989 were derived largely from the reports of chest physicians. It was only at the end of the year that the participation of occupational physicians reached a level at which their contribution began to affect the reported incidence of disease. Now that the number of occupational physicians is similar to that of chest physicians it is evident from the first few months of 1990 that the reported incidence of occupational asthma may rise by $50 \%$ or more and that of inhalation accidents may be increased manyfold. In future, greater attention will have to be given to the possibility of duplication, of which no evidence has been found so far.

Much thought was given to the question as to whether rigid diagnostic criteria should be specified. We concluded that in a surveillance scheme this would be inhibitory, and neither feasible nor desirable with diseases that vary widely in their clinical manifestations. Should further investigations be indicated, however, it would be possible then to impose strict case definitions.

Another point of concern is the extent to which the agents suspected and the occupations listed were in fact those responsible for the disease. The professional status of the reporting physicians justifies considerable confidence in diagnostic accuracy, but few clinicians are in a position to investigate work environment in any depth. There could well be a tendency to blame known causes of disease rather than agents that, although present, are not generally accepted as the source of illness. Studies to look further at this problem are planned.

It is difficult and perhaps premature to make any comparison between the findings presented in this report and other statistical sources. Despite underreporting and information derived only from consultant physicians, the number of cases reported to the SWORD project for 1989 in certain diagnostic categories were similar to the numbers awarded disablement benefit in $1988 .{ }^{6}$ One hundred and eighty six cases of asbestosis were reported to SWORD compared with 201 awards of compensation; the figures for lung cancer were 51 and 59 ; for byssinosis, 23 and 13; and for asthma due to prescribed causes, 282 and 222 respectively. It is clear, however, that acute occupational respiratory diseases are more common than official statistics would suggest. Whereas the cases of occupational asthma due to prescribed causes reported to SWORD were similar to the DSS figures, a further 272 cases were attributed to other causes. Only 15 awards of disablement benefit for farmer's lung were made in 1988 compared with 39 cases of allergic alveolitis reported to the SWORD project, and no comparable figures exist for inhalation accidents.

A useful parallel is afforded by Finland, one of the 
few countries where new cases of occupational lung disease are registered. In that country 156 new cases of asthma were notified in $1981^{7}$ in a working population of around 2.2 million ( 71 per million). This is similar to the rate of 63 per million found in the West Midlands Metropolitan County, the region with the highest reported incidence of occupational asthma. The incidence of farmer's lung, however, was much higher than that reported to the SWORD project. In Finland 59 new cases of farmer's lung were found in 1981 in an economically active agricultural population of 226000 (261 per million); comparable figures in the United Kingdom in 1989 were 26 cases of allergic alveolitis in farmers and farm workers reported to SWORD in an agricultural population of 469000 ( 55 per million).

The potential value of this surveillance scheme is more than descriptive. Collaboration of participating physicians will enable further studies to be conducted on several important issues to which this national database is ideally suited. These include investigations of agents newly suspected of causing asthma, bronchitis, allergic alveolitis, inhalation accidents, and lung cancer, as well as broader questions such as the effect of smoking and the time since first exposure on the development of asthma, the role of agents other than asbestos in mesothelioma, and the subsequent health and employment experience of patients with work related respiratory disease.
We gratefully acknowledge contributions to this project by the participating physicians and members of our advisory panels (Dr P S Burge, Dr A G Davison, Dr P C Elmes, Dr P G Harries, Dr D J Hendrick, Dr A J Newman-Taylor, Dr J Osman, Dr C A C Pickering, Professor A Seaton, and Dr J E Stark). Early phases of the project were supervised by Professor Alison McDonald and much help has since been given by other Unit staff (Linda Crombie, Elizabeth Paul, and Keith Sullivan). The work is supported by a grant from the Health and Safety Executive.

1 McDonald JC, Harrington JH. Early detection of occupational hazards. J Soc Occup Med 1981;31:93-8.

2 Thoracic medical services in the United Kingdom. London: The British Thoracic Society, 1988.

3 Office of Population Censuses and Surveys. Classification of occupations 1980. London: HMSO, 1980.

4 Gardner MJ. Tables for the calculations of confidence intervals. In: Gardner MJ, Altman DG, eds. Statistics with confidenceconfidence intervals and statistical guidelines. London: BMJ 1989;116-8.

5 Department of Health and Social Security. Social Security Act 1975-occupational asthma. London: HMSO, 1986.

6 Department of Social Security. Social security statistics 1989. London: HMSO, 1989.

7 Keskinen H. Epidemiology of occupational lung diseases: asthma and allergic alveolitis. In: Kerr JW, Ganderton MA, eds. XIth international congress of allergology and clinical immunology: proceedings of invited symposia. London: The Macmillan Press Ltd, 1983;403-7.

Accepted 2 January 1991 